\title{
Expression of disease resistance in genetically modified grapevines correlates with the contents of viral sequences in the T-DNA and global genome methylation
}

\author{
Daniela Dal Bosco • Iraci Sinski • Patrícia S. Ritschel • Umberto A. Camargo • \\ Thor V. M. Fajardo • Ricardo Harakava • Vera Quecini $\mathbb{B}$
}

Received: 1 March 2018/ Accepted: 28 May 2018

(C) Springer International Publishing AG, part of Springer Nature 2018

\begin{abstract}
Increased tolerance to pathogens is an important goal in conventional and biotechnologyassisted grapevine breeding programs worldwide. Fungal and viral pathogens cause direct losses in berry production, but also affect the quality of the final products. Precision breeding strategies allow the introduction of resistance characters in elite cultivars, although the factors determining the plant's overall performance are not fully characterized. Grapevine plants expressing defense proteins, from fungal or plant origins, or of the coat protein gene of grapevine
\end{abstract}

Electronic supplementary material The online version of this article (https://doi.org/10.1007/s11248-018-0082-1) contains supplementary material, which is available to authorized users.

D. Dal Bosco · I. Sinski · P. S. Ritschel ·

U. A. Camargo · T. V. M. Fajardo · V. Quecini $(\bowtie)$

Embrapa Uva e Vinho,

Caixa Postal 130, Bento Gonçalves, RS 95701-008, Brazil

e-mail: vera.quecini@embrapa.br

\section{R. Harakava}

Instituto Biológico, Secretaria da Agricultura e

Abastecimento, Agência Paulista de Tecnologia dos

Agronegocios (APTA), Av. Conselheiro Rodrigues Alves

1252, São Paulo, SP 04014-002, Brazil

\section{Quecini}

CNPUV (National Center for Grapevine and Wine

Research), Embrapa (Brazilian Agricultural Corporation), Rua Livramento, 515, Bento Gonçalves, RS 95701-008, Brazil leafroll-associated virus 3 (GLRaV-3) were generated by Agrobacterium-mediated transformation of somatic embryos and shoot apical meristems. The responses of the transformed lines to pathogen challenges were investigated by biochemical, phytopathological and molecular methods. The expression of a Metarhizium anisopliae chitinase gene delayed pathogenesis and disease progression against the necrotrophic pathogen Botrytis cinerea. Modified lines expressing a Solanum nigrum osmotin-like protein also exhibited slower disease progression, but to a smaller extent. Grapevine lines carrying two hairpininducing constructs had lower GLRaV-3 titers when challenged by grafting, although disease symptoms and viral multiplication were detected. The levels of global genome methylation were determined for the genetically engineered lines, and correlation analyses demonstrated the association between higher levels of methylated DNA and larger portions of virus-derived sequences. Resistance expression was also negatively correlated with the contents of introduced viral sequences and genome methylation, indicating that the effectiveness of resistance strategies employing sequences of viral origin is subject to epigenetic regulation in grapevine.

Keywords Chitinase - Epigenetics · Fungus · Grapevine leafroll-associated virus 3 - Pathogenesis related protein $5 \cdot$ Vitis 


\section{Introduction}

Grapevine diseases caused by viruses and fungi impose severe economic losses, not only due to their direct effect on production and yield, but also by modifications of berry metabolism, which result in lower contents of soluble solids and increased acidity (Burger et al. 2017; Gadoury et al. 2007). Moreover, pathogen induced modifications in the fruit specialized metabolism are carried over to the final products, compromising their quality and fitness for consumption (Gadoury et al. 2007). Chemical control remains a major recommendation in global protection strategies against fungal diseases, whereas the combat of viral pathogens relies on prophylactic measures, such as the eradication of symptomatic plants, and reintroduction of virus-free certified material.

Genetic engineering is particularly attractive to improve plant tolerance and resistance to pathogens in perennial species, where conventional breeding is challenging due to severe inbreeding depression, long lifecycle, and lack of knowledge on resistance genes or genetic architecture of the trait (Gray et al. 2014). Moreover, worldwide viticulture largely relies on a restricted number of Vitis vinifera elite cultivars, and is reluctant to accept novel and hybrid cultivars, bred for pathogen resistance or tolerance purposes. Genetic engineering for disease resistance has been extensively used in grapevine (review in Gray et al. 2014), with various degrees of success. For fungal and bacterial diseases, the design of genetically engineered plants expressing proteins with antimicrobial activity, either from plants or other organisms, has been one of the most common strategies used (Breen et al. 2015). The coding sequences of pathogenesis-related (PR) proteins from wild Vitis species or other sexually incompatible plants and microorganisms were used to produce transgenic grapevines aiming fungus resistance (Gray et al. 2014). In contrast, virus resistance is frequently sought after by the introduction of viral genomic sequences into the plant host genome (Maliogka et al. 2015). Sequences derived from virus coat protein $(\mathrm{CP})$ have been widely used in grapevine to induce resistance (Gambino et al. 2005, 2010; JardakJamoussi et al. 2009; Mauro et al. 1995; Valat et al. 2006; Vigne et al. 2004).

In plants, the introduction and expression of foreign sequences and the presence of RNA pathogens has led to the discovery of various homology-dependent gene- silencing mechanisms associated to changes in DNA methylation (Hewezi et al. 2017; Matzke et al. 2015). Three context of DNA methylation have been described in plants; $\mathrm{CG}, \mathrm{CHG}$, and $\mathrm{CHH}$ (where $\mathrm{H}$ is $\mathrm{A}, \mathrm{C}$ or $\mathrm{T}$ ), requiring distinct mechanisms for their establishment and maintenance, and showing different effects on DNA sequences (Matzke et al. 2015). Frequently, gene expression is shut down in genome regions methylated for all three contexts, and the repression can sometimes be extended to neighboring locations (Hewezi et al. 2017; Matzke et al. 2015). Global genome methylation has been associated with gene expression changes in developmental control, evolutionary processes, and responses to environmental conditions in plants (Lewsey et al. 2016; Matzke et al. 2015). In grapevine, distinct local levels of methylation were associated to post-transcriptional gene silencing (PTGS) of viral sequences (Gambino et al. 2010) and silencing of virus-derived sequences could be induced by artificial micro RNAs (Jelly et al. 2012). The influence of exogenous sequence contexts on genome methylation and transgene expression in grapevine remains elusive.

In the this study, we have investigated the responses of genetically engineered grapevines to fungal and viral pathogens using plants obtained from distinct transformation methods, carrying exogenous sequences from different origins, and devised to induce resistance by distinct mechanisms. Moreover, multivariated and correlation analyses were performed to provide further insight on the effect of the molecular features of the transgenic plants on the expression of the resistance mechanisms in vivo.

\section{Materials and methods}

Plant material

Grapevine cultivars were obtained from the Germplasm Bank at Embrapa, and include a seedless cultivar, BRS Clara (Camargo et al. 2003) and the wine cultivar Chardonnay. 'BRS Clara' is a genotype with more than $85 \%$ of $V$. vinifera genome and indistinguishable responses to $B$. cinerea and grapevine leafroll-associated virus 3 (GLRaV-3) (Camargo et al. 2003). Accessions were provided as woody cuttings containing flower or vegetative buds, for somatic embryogenesis and in vitro plant propagation, 
respectively. Genetic transformation of 'Chardonnay' and 'BRS Clara' employed somatic embryos (SE) and shoot apical meristems (SAM) as explants (Fig. 1, Fig. S1). Timeline for explant production, genetic transformation and plant analyses are schematically represented in Supplementary Fig. 1 (Fig. S1).

\section{Genetic transformation binary vectors}

The cDNA sequences of proteins with antimicrobial activity, namely, a chitinase from Metarhizium anisopliae (MaCHIT1) (GenBank accession AF027498) (Bogo et al. 1998) and an osmotin-like from Solanum nigrum (SnOLP) (GenBank accession AF450276) were excised from pMOG463 (Mogen, The Netherlands) and pCambia1390 (Cambia, Australia) by digestion with EcoRV/BamHI and HindIII/EcoRI, respectively. The resulting fragments of $1.7 \mathrm{~kb}$ and 752 bp were gel purified with PureLink ${ }^{\mathrm{TM}}$ Quick Gel Extraction Kit (ThermoFischer Scientific, USA) and ligated to pCambia1304 at the multicloning site.

For cloning of MaCHIT1, pCambia1304 was digested with EcoRI, the $5^{\prime}$ overhangs filled with DNA Polymerase I, Large (Klenow) Fragment (New England Biolabs Inc., USA) according to the manufacturer's instructions and, subsequently, digested with BamHI. The transformation vector was labeled pMaCHIT1. For cloning of the SnOLP sequence, the $5^{\prime}$ overhangs of the digested fragment were blunted as described, purified by chloroform wash followed by ethanol precipitation and digested with EcoRI. The processed $S n O L P$ fragment was ligated to pCambia1304 digested with EcoRI, resulting in transformation vector $\mathrm{pSnOLP}$.

Two hairpin RNA constructs employing the $3^{\prime}$ or $5^{\prime}$ ends of the gene coding for the capsid protein (CP) of a Brazilian isolate of Grapevine leafroll-associated virus 3 (GLRaV-3) (GenBank accession AY753208) (Fajardo et al. 2007) were used. The fragments were amplified by polymerase chain reaction (PCR) using primers containing PstI/NcoI and $S a c \mathrm{I} / K p n \mathrm{I}$ restriction sites. The oligonucleotides used in the current work are described in Supplementary Table 1 (Table S1). The sense and antisense fragments were stepwise cloned at the $N c o \mathrm{I} / K p n \mathrm{I}$ and PstI/SacI restriction sites of a vector containing the intron (426 bp) of a citrus CHITINASE (CHI) gene (GenBank accession AJPS01004869.1 from 32,028 to $33,224)$ as spacer to form the hairpin structure. The fragments containing 'senseCP-intron-antisenseCP' for the $5^{\prime}$ and $3^{\prime}$ extremities of the viral gene were removed by EcoRI/HindIII double-digestion and cloned independently to pCambia1304. Cloning of the fragments was determined by restriction analyses, and one clone was selected for each gene end (pGLR3$3^{\prime}$ and pGLR3-5').

The structure and integrity of the sequences in the T-DNA in the binary vectors pMaCHIT1, pSnOLP, pGLR3-3' and pGLR3-5' were confirmed by sequencing and are schematically represented in Fig. 2. Purified binary vectors were employed to transform electrocompetent Agrobacterium tumefaciens EHA105.

Grapevine genetic transformation

Shoot apical meristems were transformed as described by Dutt et al. (2007) with the following modifications: the increase of explant mass was initiated with ten freshly excised shoots tips of approximately $1 \mathrm{~cm}$ in length, cultivated in $25 \mathrm{~mL}$ liquid C2D4B for 4 weeks under diffuse light with mild shaking $(100 \mathrm{rpm})$ at $23{ }^{\circ} \mathrm{C}$, and the blot dried explants were immediately used in transformation experiments, without the solid medium cultivation step (Fig. 1a, b). The explants were wounded by nicking with a fine pointed scalpel blade during the blotting step. After cocultivation, the explants were transferred to plates containing regeneration medium, consisting of MS (Murashige and Skoog 1962) basal salts, B5 vitamins (Gamborg et al. 1968), $30 \mathrm{~g} \mathrm{~L}^{-1}$ sucrose, $9.0 \mu \mathrm{M}$ 6-benzylaminopurine (BAP), $0.1 \mu \mathrm{M}$ naphthalene acetic acid (NAA), $200 \mathrm{mg} \mathrm{L}^{-1}$ carbenicillin, $200 \mathrm{mg} \mathrm{L}^{-1}$ cefotaxime, $25 \mathrm{mg} \mathrm{L}^{-1}$ hygromycin and solidified with $6.5 \mathrm{~g} \mathrm{~L}^{-1}$ agar. Medium $\mathrm{pH}$ was adjusted to 5.8 prior to autoclaving.

Somatic embryos were transformed as described by Li et al. (2006), except that embryos were precultured on fresh GS1CA medium (Iocco et al. 2001) for 6 days before transformation, and after cocultivation, the explants were washed in liquid GS1CA supplemented with $200 \mathrm{mg} \mathrm{L}^{-1}$ carbenicillin and $200 \mathrm{mg} \mathrm{L}^{-1}$ cefotaxime, before transfer to regeneration medium, consisting of GS1CA supplemented with $200 \mathrm{mg} \mathrm{L}^{-1}$ carbenicillin, $200 \mathrm{mg} \mathrm{L}^{-1}$ cefotaxime and $25 \mathrm{mg} \mathrm{L}^{-1}$ hygromycin, for 10 days, in the dark at $23 \pm 2{ }^{\circ} \mathrm{C}$ (Fig. 1a, b). Individualized embryos able to form roots in hygromycin containing media 


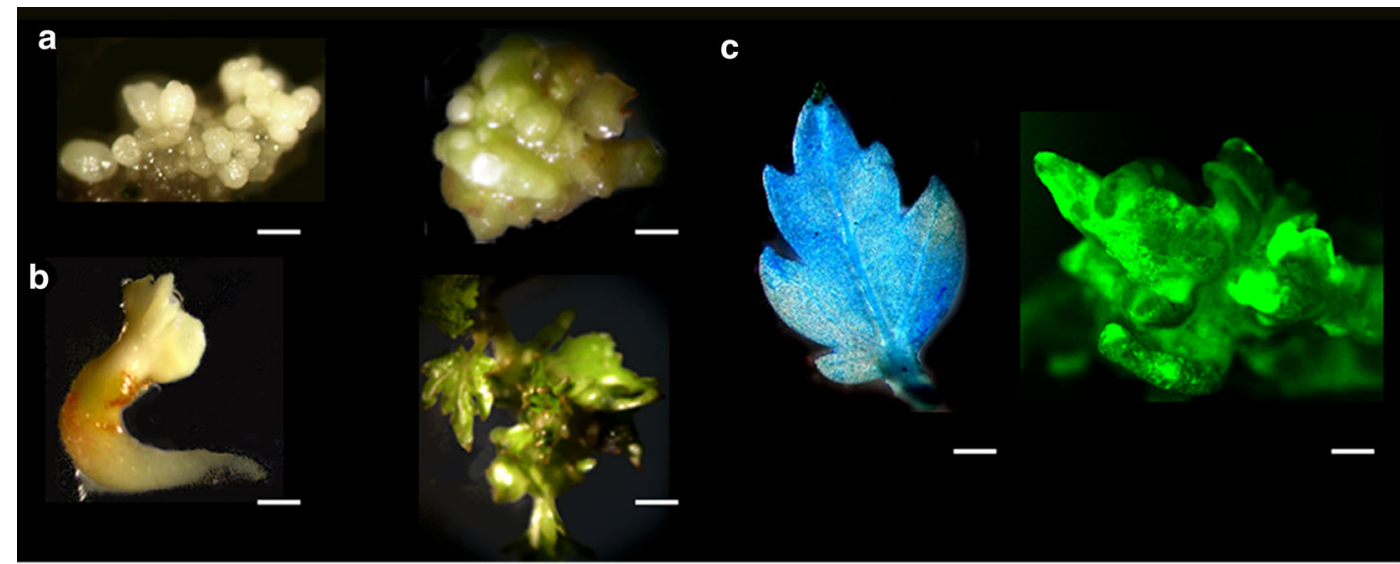

d

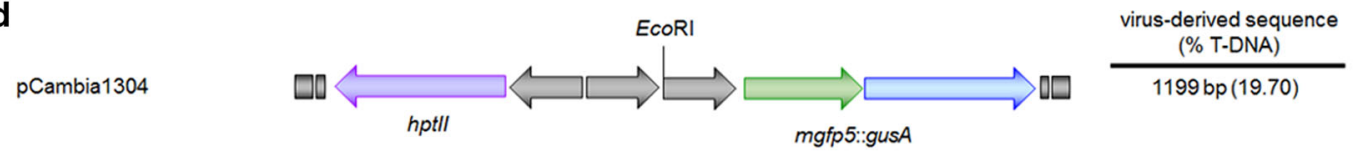

PMaCHIT1
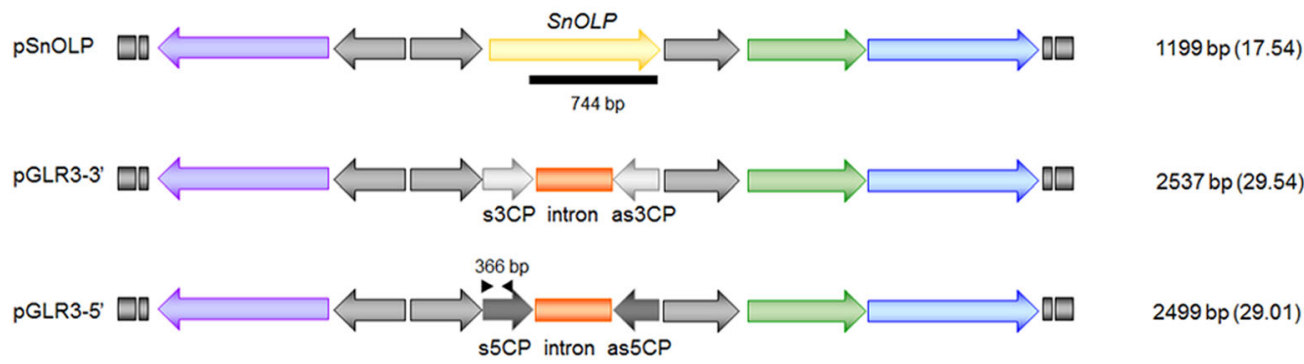

e

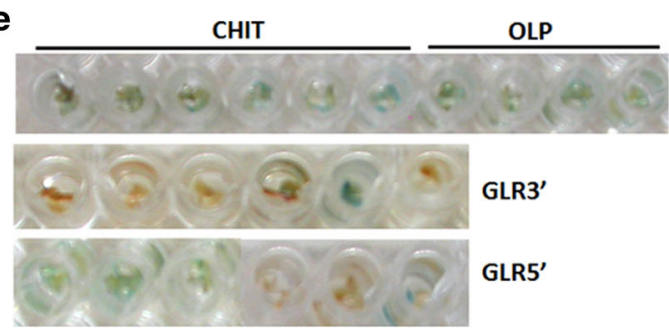

g pMaCHIT1

BRS Clara Chardonnay

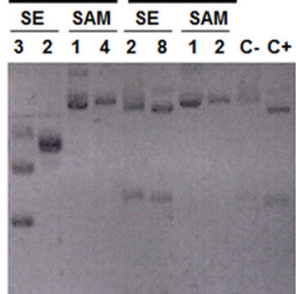

pSnOLP

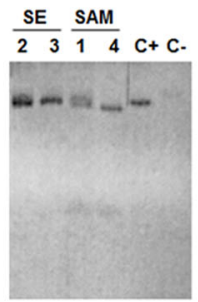

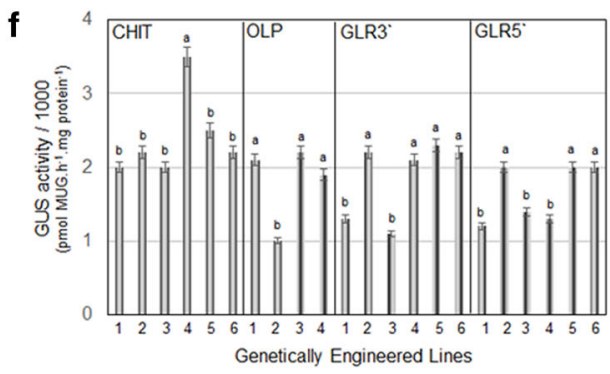

pGLR3-3'

PGLR3-5'

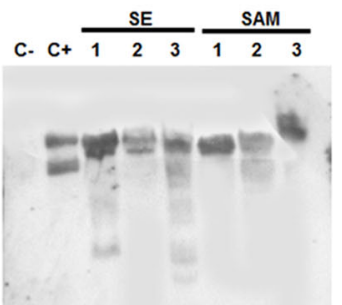

$C+C-\frac{S E}{1} \frac{2}{3} \frac{3 A M}{1} \frac{2}{3}$

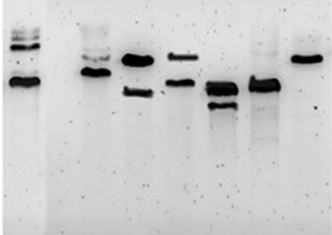


\Fig. 1 Grapevine genetic engineering. Somatic embryos (SE) (left hand panel) and shoot apical meristem (SAM) (right hand panel) explants (a), regeneration (b) and GUS and GFP reporter gene expression in regenerated, rooted plantlets (c). Scale bar corresponds to $1 \mathrm{~cm}$. Schematic representation of T-DNA regions of the vectors used to transform grapevine with the percentage of virus-derived sequence (d). Arrows represent $5^{\prime}-$ $3^{\prime}$ sequenced direction in the vector. Plant selection marker HYGROMYCIN PHOSPHOTRANSFERASE (HPTII) is represented in purple, reporter translational fusion mgfp $5:: g u s A$ is shown in green and blue. Regulatory sequences CaMV35S promoter and NOPALINE SYNTHASE (NOS) polyadenylation signal, along with T-DNA borders are shown in gray, as arrows and bars, respectively. Hairpin-inducing viral sequences are represented as arrows for $3^{\prime}$ or $5^{\prime}$ coat protein (3CP or 5CP) coding sequences in sense (s) and antisense (as) orientation. Citrus CHITINASE intron is represented in orange. Position of a single cutter restriction enzyme (EcoRI) in the multicloning site of the transformation vectors is represented. DNA and RNA hybridization probes correspond to the T-DNA for all vectors, and to underlined fragments in pMaCHIT1 and pSnOLP. The position of PCR primers in the $5^{\prime}$ hpGLR3 line is represented by arrowheads, and the size of the amplified fragment, in base pairs. e Histochemical analyses of GUS expression in regenerated plants. f Fluorometric analyses of GUS activity in regenerated lines. Letters represent Tukey's HSD at $p<0.05$ (one-way ANOVA). g Hybridization of EcoRI digested genomic DNA from transformed grapevine lines with T-DNA probes from the vectors used for genetic transformation. Negative control $(\mathrm{C}-$ ) correspond to DNA from wild-type, non-engineered plants, and positive control $(\mathrm{C}+)$ to linear plasmid DNA (10 ng). (Color figure online)

(Fig. 1a, b) were checked for the presence and expression of the transgene by PCR and $\beta$-glucuronidase assays, respectively (Fig. 1a-c)

Molecular characterization and expression analyses

DNA hybridization analyses were used to confirm the stable insertion of the transgenes in the host genomes. Briefly, $15 \mu \mathrm{g}$ of genomic DNA, extracted as described by Lodhi et al. (1994), were completely digested with EcoRI, which cuts once in the T-DNA, resolved on $1 \mathrm{X}$ TAE $0.7 \%(\mathrm{w} / \mathrm{v})$ agarose gel and blotted to Amersham Hybond $\mathrm{N}^{+}$membranes (GE Healthcare and Lifesciences, USA). Sequences between the T-DNA borders were gel purified as probes (Fig. 1d) and labelled with alkaline phosphatase using AlkPhos Direct Labeling and Detection $^{\mathrm{TM}}$ (GE Healthcare and Lifesciences, USA). Membranes were prehybridized for $60 \mathrm{~min}$ at $55^{\circ} \mathrm{C}$ with gentle shaking (60 rpm). Subsequently, $10 \mathrm{ng}$ of labelled probe were added to the prehybridization solution and the membranes hybridized for $16 \mathrm{~h}$ at $55^{\circ} \mathrm{C}$. Blots were washed according to the manufacturer's instructions, and the CDP-Star ${ }^{\mathrm{TM}}$ reagent (GE Healthcare and Lifesciences, USA) was used to generate the chemiluminescent signal, detected on Amersham Hyperfilm ECL (GE Healthcare and Lifesciences, USA).

The transcription of the genes coding for exogenous proteins with antimicrobial activity was evaluated by RNA hybridization. A total of $12 \mu \mathrm{g}$ of total RNA, extracted as described by Gambino et al. (2008), were resolved on $1 \mathrm{X}$ MOPS $0.7 \%(\mathrm{w} / \mathrm{v})$ agarose denaturing gels. Nucleic acid transfer to the membrane, probe labelling and chemiluminescence detection were performed as described, except that the probes consisted of gel purified MaCHIT1 and SnOLP fragments, instead of the whole T-DNAs as used for DNA hybridization (Fig. 1d). Reporter gene expression was determined by histochemical and fluorometric analyses for gus A, and fluorescent microscopy at $395 \mathrm{~nm}$, for egfp5. Reporter expression levels are represented as scale, ranging from low $(+)$ to high $(+++)$ expression levels for gusA and egfp5. Expression levels were consistent for the reporter genes in all investigated lines.

\section{Disease response analyses}

Independently transformed, non-chimeric lines were randomly chosen for analyses, namely: two 'BRS Clara' and one 'Chardonnay' lines carrying pMaCHIT1, two 'Chardonnay' and one 'BRS Clara' carrying pSnOLP, six 'Chardonnay' lines carrying pGLR3-3' and six, pGLR3-5'; along with pCambia 1304 transformed and wild type 'BRS Clara' and 'Chardonnay' controls. The chosen lines were in vitro propagated and, at least five plants of each line, were employed on pathogen challenging. The investigated lines were obtained from both regeneration systems, namely, shoot apical meristem (SAM) and somatic embryo (SE) transformation (Table 1, Fig. S2).

\section{Botrytis cinerea infection assay}

A local isolate of $B$. cinerea from the fungal pathogen collection at Embrapa was used. Monosporic cultures were plated on potato-dextrose-agar (PDA) medium in Petri dishes at $25{ }^{\circ} \mathrm{C}$ in the dark. Prior to inoculation, 
Fig. 2 Disease response assays for chitinase (a-d), osmotin-like protein (eg) and GLRaV-3 (h-j). Six representative chitinase and osmotin-like expressing lines were chosen for pathogen challenge. The lines are identified as CHIT1, CHIT2, CHIT3, OLP1, OLP2 and OLP3 in Table 1. Leafroll disease evaluation in response to grafting with GLRaV-3 was carried out for 12 lines, described in Table 1. a In vitro assay of chitinase activity. Letters represent Tukey's HSD at $p<0.05$ (one-way ANOVA). b RNA hybridization employing a gene-specific probe.

c Disease progression evaluated by the percentage of damaged leaf area after infection. d Light microscopy analyses of fungal structures in infected leaf discs at day 9. e Disease progression evaluated by the percentage of damaged leaf area after infection. f RNA hybridization employing a gene-specific probe. $\mathrm{g}$ Light microscopy analyses of fungal structures in infected leaf discs at day 5 .

$\mathbf{h}$ Frequency and intensity of leafroll symptom in hpGLR3 lines. i RT-PCR amplification of a GLRaV-3 specific fragment in symptomatic engineered plants. j Heatmap representation of GLRaV-3 coat protein levels detected by ELISA in genetic engineered and wild-type control plants. (Color figure online)

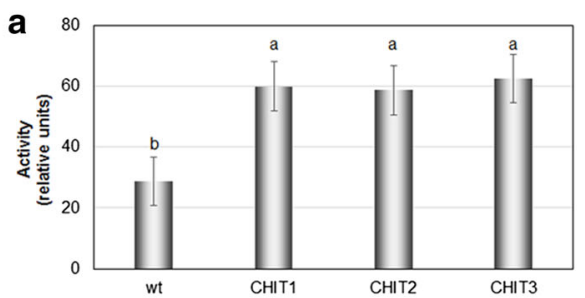

b

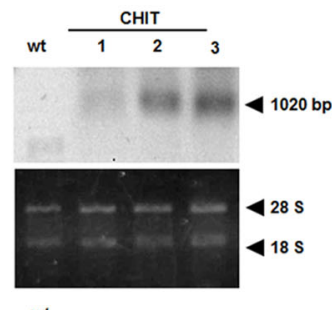

C

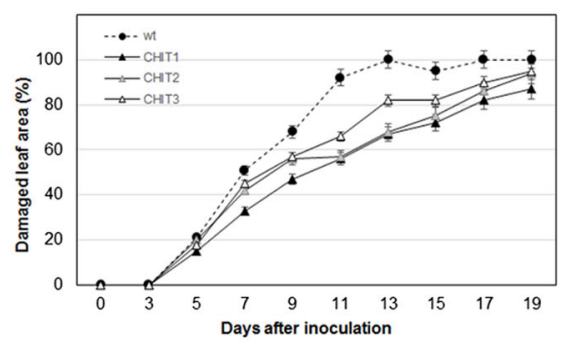

d
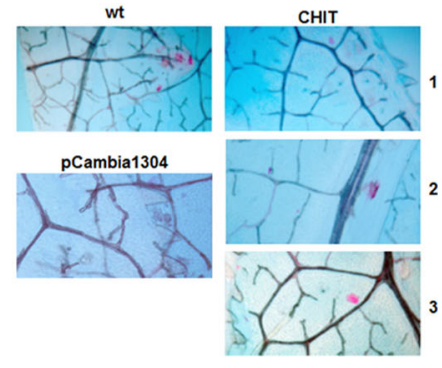

e

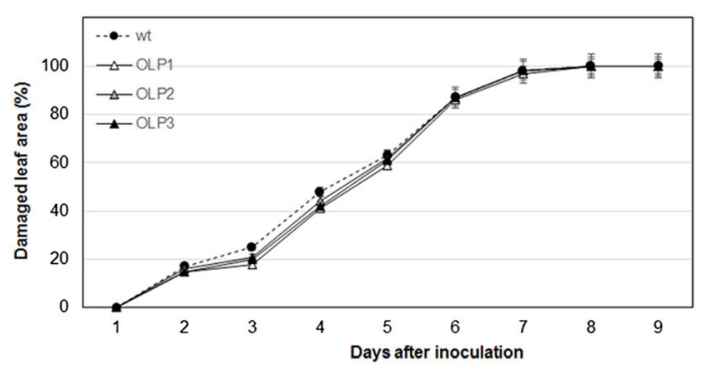

f

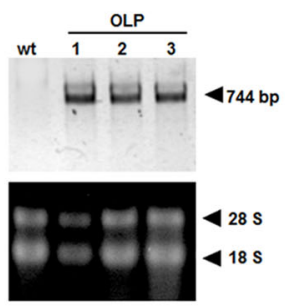

h

\begin{tabular}{ccc} 
& \multicolumn{2}{c}{ leafroll symptom } \\
\cline { 2 - 3 } line & intensity & frequency \\
\hline GLR3-3' SE1 & + & $>1 / 8$ \\
SE2 & + & $>1 / 8$ \\
SE3 & + & $>1 / 8$ \\
SAM1 & faint & $>1 / 8$ \\
SAM2 & + & $>1 / 8$ \\
SAM3 & + & $>1 / 8$ \\
GLR3-5' SE1 & + & $>1 / 8$ \\
SE2 & + & $>1 / 8$ \\
SE3 & + & $>1 / 8$ \\
SAM1 & + & $>1 / 8$ \\
SAM2 & + & $>1 / 8$ \\
SAM3 & + & $>1 / 8$ \\
\hline
\end{tabular}

i g
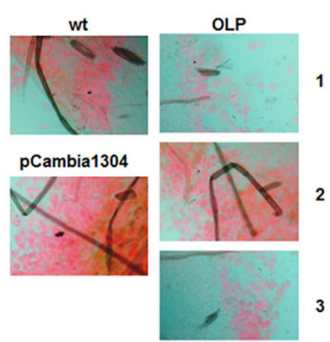

j

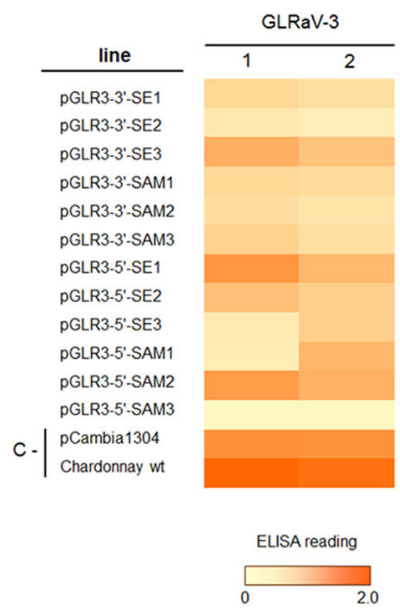


Table 1 Characterization of the genetically engineering and control grapevine lines used in pathogen challenge assays

\begin{tabular}{|c|c|c|c|c|c|c|c|}
\hline \multirow[t]{2}{*}{ Line } & \multirow[t]{2}{*}{ Species } & \multirow[t]{2}{*}{ Cultivar } & \multirow[t]{2}{*}{ Explant } & \multirow[t]{2}{*}{ Gene of interest } & \multirow[t]{2}{*}{ T DNA copy number } & \multicolumn{2}{|l|}{ Expression level } \\
\hline & & & & & & Gene of interest & Reporter \\
\hline CHIT1 & Vitis hybrid & BRS Clara & SAM & MaCHIT1 & 1 & ++ & ++ \\
\hline CHIT2 & Vitis vinifera & Chardonnay & SE & MaCHIT1 & 2 & +++ & ++ \\
\hline CHIT3 & Vitis hybrid & BRS Clara & SE & MaCHIT1 & 3 & +++ & +++ \\
\hline CHIT4 & Vitis hybrid & BRS Clara & SAM & MaCHIT1 & 1 & ++ & ++ \\
\hline CHIT5 & V. vinifera & Chardonnay & SAM & MaCHIT1 & 1 & ++ & ++ \\
\hline CHIT6 & Vitis hybrid & BRS Clara & $\mathrm{SE}$ & MaCHIT1 & 1 & + & ++ \\
\hline CHIT7 & $V$. vinifera & Chardonnay & SAM & MaCHIT1 & 1 & +++ & ++ \\
\hline CHIT8 & V. vinifera & Chardonnay & SE & MaCHIT1 & 2 & ++ & + \\
\hline OLP1 & Vitis vinifera & Chardonnay & SAM & SnOLP & 2 & +++ & ++ \\
\hline OLP2 & Vitis hybrid & BRS Clara & $\mathrm{SE}$ & SnOLP & 1 & +++ & + \\
\hline OLP3 & Vitis vinifera & Chardonnay & SE & SnOLP & 1 & +++ & ++ \\
\hline OLP4 & Vitis hybrid & BRS Clara & SAM & SnOLP & 2 & ++ & ++ \\
\hline GLR3'-1 & $V$. vinifera & Chardonnay & SAM & hpGLR3' & 2 & nd & + \\
\hline GLR3'-2 & $V$. vinifera & Chardonnay & SAM & hpGLR3' & 1 & nd & ++ \\
\hline GLR3'-3 & $V$. vinifera & Chardonnay & SAM & hpGLR3' & 2 & nd & ++ \\
\hline GLR3'-4 & V. vinifera & Chardonnay & SE & hpGLR3' & 1 & nd & ++ \\
\hline $\mathrm{GLR}^{\prime}-5$ & V. vinifera & Chardonnay & SE & hpGLR3' & 1 & nd & + \\
\hline GLR3'-6 & $V$. vinifera & Chardonnay & SE & hpGLR3' & 1 & nd & ++ \\
\hline $\mathrm{GLR}^{\prime}-1$ & V. vinifera & Chardonnay & SAM & hpGLR5' & 2 & nd & + \\
\hline GLR5'-2 & $V$. vinifera & Chardonnay & SAM & hpGLR5' & 2 & nd & + \\
\hline GLR5'-3 $^{\prime}$ & V. vinifera & Chardonnay & SAM & hpGLR5' & 2 & nd & ++ \\
\hline GLR5'-4 & V. vinifera & Chardonnay & SE & hpGLR5' & 2 & nd & ++ \\
\hline GLR5'-5 & V. vinifera & Chardonnay & SE & hpGLR5' & 1 & nd & ++ \\
\hline GLR5'-6 & $V$. vinifera & Chardonnay & SE & hpGLR5' & 1 & nd & +++ \\
\hline p1304 & Vitis hybrid & BRS Clara & SAM & na & 2 & na & ++ \\
\hline p1304 & Vitis hybrid & BRS Clara & SE & na & 1 & na & ++ \\
\hline p1304 & $V$. vinifera & Chardonnay & SAM & na & 2 & na & ++ \\
\hline p1304 & V. vinifera & Chardonnay & $\mathrm{SE}$ & na & 1 & na & + \\
\hline wt & Vitis hybrid & BRS Clara & SAM & na & 0 & na & na \\
\hline wt & Vitis hybrid & BRS Clara & SE & na & 0 & na & na \\
\hline wt & $V$. vinifera & Chardonnay & SAM & na & 0 & na & na \\
\hline $\mathrm{wt}$ & $V$. vinifera & Chardonnay & $\mathrm{SE}$ & na & 0 & na & na \\
\hline
\end{tabular}

The number of inserted T DNA copies was determined by DNA hybridization. Expression analyses were carried out using the original transformed line (T0), prior to plant propagation. Expression levels were determined by RNA hybridization for the genes of interest, and fluorometric assay for GUSA. Expression levels are represented as $(+)$ low, intermediate $(++)$ and $(+++)$ high scale CHIT, Metarhizium anisopliae CHITINASE1; GLR, $3^{\prime}$ or $5^{\prime}$ fragment of the coat protein (CP) gene from Grapevine leafrollassociated virus 3 (GLRaV-3); OLP, Solanum nigrum OSMOTIN-LIKE1; na, non-available; nd, not determined; p1304, binary vector pCambia1304; wt, wild type

isolated spores were transferred to fresh medium and incubated at $20{ }^{\circ} \mathrm{C}$, under a $16 \mathrm{~h}$ photoperiod, until complete fungal growth (approximately 7 days). The adaxial surface of freshly detached leaves from in vitro plants (third fully expanded leaf from the top down) were inoculated by contact with agar slices $(5 \mathrm{~mm}$ diameter) containing the grown fungus. Inoculated leaves were incubated as previously on magenta boxes 
Fig. 3 Quantitative analyses of global genome methylation (ng) in CHIT, OLP and hp-GLR3 engineered grapevine lines. The amount of methylated DNA in plants carrying the empty vector (pCambia1304) and wildtype controls is shown in the insert. Wild type controls correspond to the average global methylation of 'BRS Clara' and 'Chardonnay' plants regenerated in vitro via somatic embryogenesis and direct organogenesis of shoot apical meristems. (Color figure online)

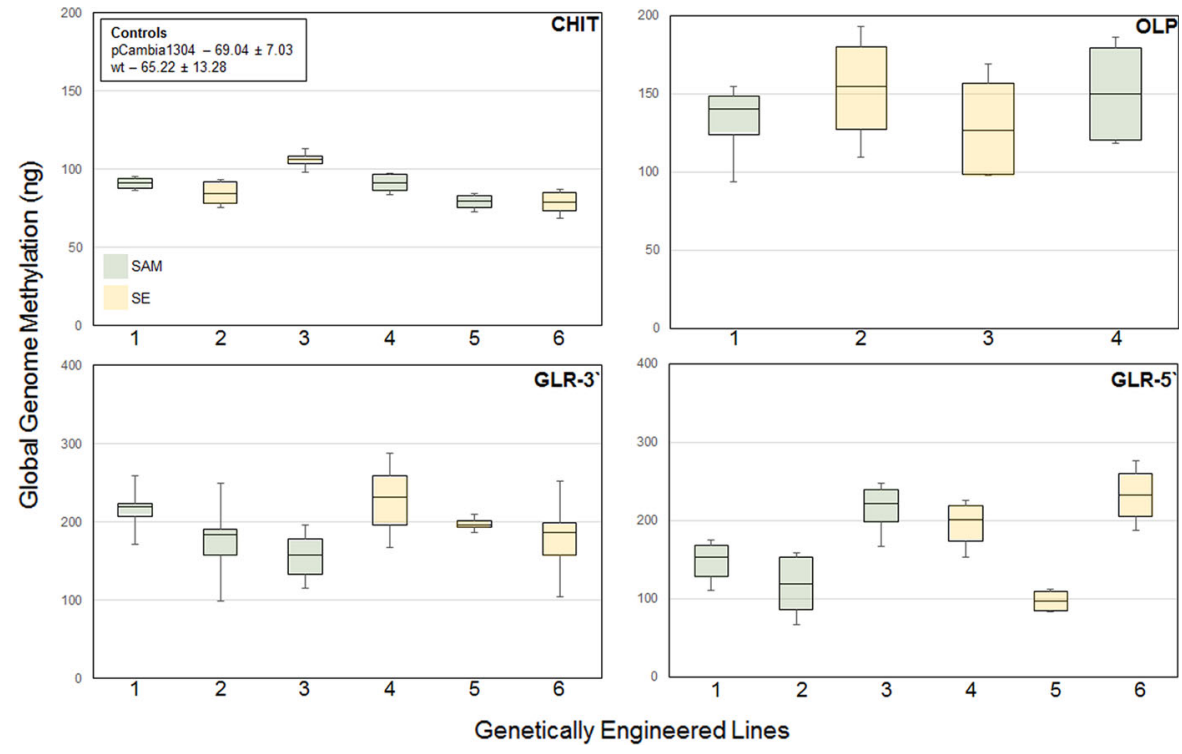

containing sterile moist filter paper, employing sterile rubber meshes to prevent direct contact with the wet filter paper. Negative controls consisted of agar slices without fungus. Five representative leaves from each treatment were digitally imaged daily after inoculation and lesions were measured using ImageJ 1.8 (Schneider et al. 2012). Plant tissue colonization by fungal structures was visualized by light microscopy in leaves cleared by chloral hydrate and stained by Schiff's reagent.

\section{Chitinase activity assay}

Total protein extracts were obtained from $100 \mathrm{mg}$ of fresh plant tissue, finely ground in $1 \mathrm{~mL}$ of extraction buffer (100 mM acetate buffer; $\mathrm{pH} 5.0,0.5 \mathrm{M} \mathrm{NaCl}$, $1 \%(\mathrm{w} / \mathrm{v})$ polyvinylpyrrolidone (PVP40), $0.1 \%$ Triton $\mathrm{X}-100,2 \%(\mathrm{v} / \mathrm{v}) \beta$-mercaptoethanol and $20(\mathrm{v} / \mathrm{v}) \%$ glycerol). The mixture was incubated at $25{ }^{\circ} \mathrm{C}$ for $3 \mathrm{~h}$, centrifuged at $5000 \mathrm{~g}$ for $5 \mathrm{~min}$ and the clear supernatant employed for protein quantification using the Bradford method. Protein extracts $(150 \mu \mathrm{L})$ were added to the reaction mixture consisting of $0.1 \%$ colloidal chitin $(300 \mu \mathrm{L})$ and $0.1 \mathrm{M}$ phosphate buffer $\mathrm{pH} 7.0(150 \mu \mathrm{L})$, incubated at $55^{\circ} \mathrm{C}$ for $10 \mathrm{~min}$ and centrifuged at $4{ }^{\circ} \mathrm{C}$ at $10,000 \mathrm{~g}$ for $5 \mathrm{~min}$. The supernatant $(200 \mu \mathrm{L})$ was added to $500 \mathrm{~mL}$ of deionized water and $1 \mathrm{~mL}$ of Schales reagent $(0.5 \mathrm{M}$ sodium carbonate and $0.5 \mathrm{~g} \mathrm{~L}^{-1}$ potassium ferricyanide in water), and boiled for $10 \mathrm{~min}$. The absorbance of the cooled mixture was determined spectrophotometrically at $420 \mathrm{~nm}$.

Virus symptom and serological analyses

Lateral buds of approximately $1.2 \mathrm{~cm}$ in diameter were removed from 'Chardonnay' stock plants, positive for GLRaV-3 infection, determined by RT-PCR, and used as inoculum source. The buds were grafted to the stems of lignified plants carrying the hp-inducing construct, approximately 28 months after ex vitro acclimation. The responses to viral infection were evaluated by visual score of leaf roll symptoms and by two independent serological analyses, approximately 210 days after grafting. For virus titer determination, phloem samples were scraped from mature canes, and the crude extracts were diluted at 1:1.5 (w/v) to be used in Double Antibody Sandwich Enzyme-Linked Immunosorbent Assay (DAS-ELISA) with polyclonal antisera against GLRaV-3 [IgG and conjugated antibody at 1:250 (v/v) from Agritest (Valenzano, Italy)].

Determination of global genome methylation

Global DNA methylation was quantified using Imprint ${ }^{\circledR}$ Methylated DNA Quantification Kit (Sigma Aldrich, USA) for triplicates of DNA isolation experiments from transgenic grapevine lines, methylated and blank controls, and duplicated absorbance readings according to the manufacturer's instructions. 
a

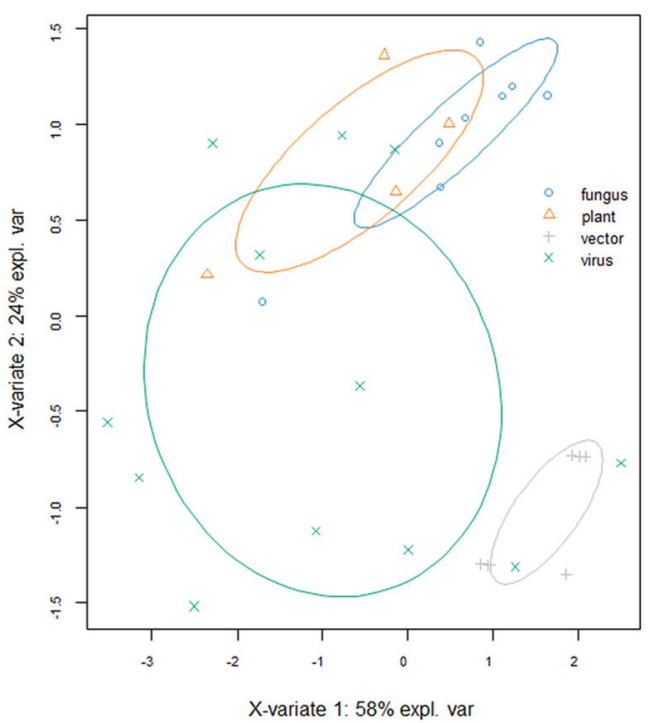

C

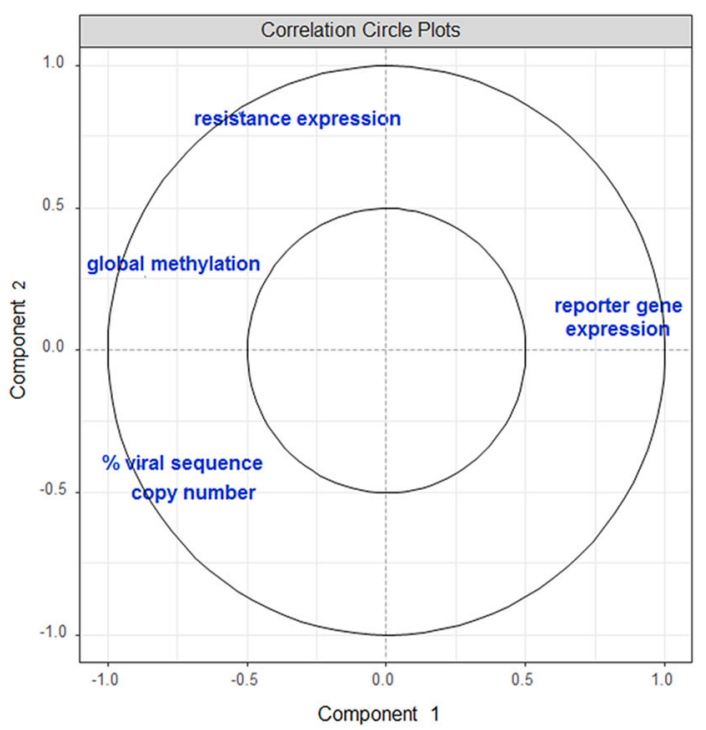

Fig. 4 Multivariate analyses of the transgene copy number, percentage of viral sequences, global genome methylation, and reporter gene and resistance expression in grapevine genetically engineered lines. a sPLS-DA plot of the individuals using the origin of the gene of interest as discriminant. Ellipses represent 95\% confidence levels. b Clustered image map of the similarity matrix obtained by sPLS-DA results. Similarity is represented as heatmap, ranging from -2.2 (blue) to 2.2 (red), and

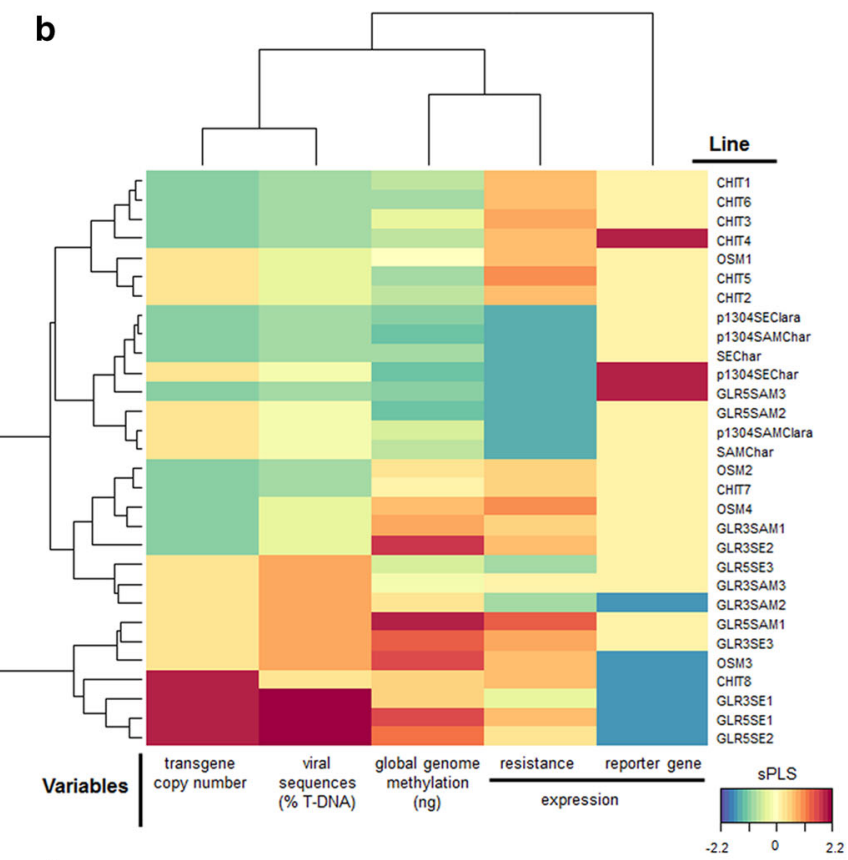

d
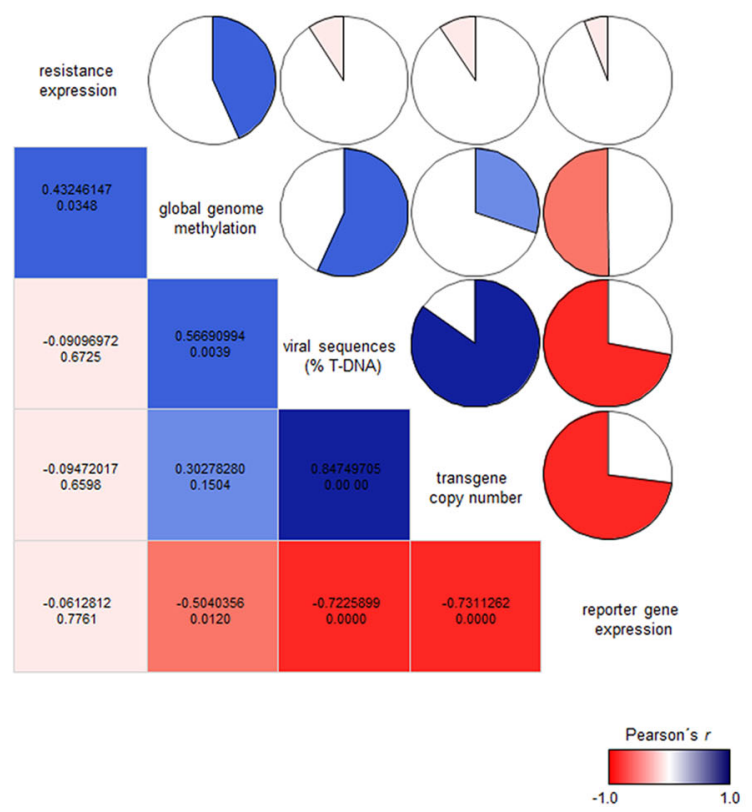

dendrograms derived from hierarchical clustering of the similarity results are represented for the genetically engineered lines (vertical) and variables (horizontal). c Correlation circle plot of the variables used in sPLS-DA analysis. $\mathbf{d}$ Heatmap and pie graph representation of the Pearson correlation between the investigated variables for the genetically engineered grapevine CHIT, OLP and hp-GLR3 lines. Pearson's $r$ is given inside the squares along with its $p$ value. (Color figure online) 
DNA concentration was spectrophotometrically determined and adjusted to $500 \mathrm{ng}$. Contents of methylated DNA were determined by regression analysis of the standard curve generated by subtracting the absorbance readings at $450 \mathrm{~nm}\left(\mathrm{~A}_{450}\right)$ from the methylated $\left(\mathrm{A}_{450} \mathrm{MC}\right)$ and blank $\left(\mathrm{A}_{450} \mathrm{~B}\right)$ controls versus the mass (ng) of methylated DNA for each point read. Data points for methylation quantification standard curve are presented in Supplementary Fig. 3 (Fig. S3).

\section{Statistical analyses}

Data were processed and analyzed in $\mathrm{R}$ ( $\mathrm{R}$ Core Team 2015), using F statistics and Waller-Duncan $k$-ratio $t$ test at $p<0.05$. Regression analyses were done employing the fit function, and regression diagnosis was carried out by investigation of heteroscedasticity, normality, multicollinearity, non-linearity, and non-independence of errors, with the car package (Fox and Weisberg 2011). Multivariate analyses principal component analysis (PCA) and sparse partial least squares discriminant analysis (sPLS-DA) were performed and graphed using the mixOmics package (Lê Cao et al. 2016). Hierarchical clustering was done by simultaneously grouping rows and columns of the real-valued similarity matrix generated by sPLS-DA (Lê Cao et al. 2016). Pearson correlation analysis and its significance were calculated using Hmisc (Harrell Jr et al. 2017) and plotted employing the corrgram package (Wright 2017).

\section{Results}

Genetic engineering, transgene insertion and expression

Somatic embryos and shoot apical meristems were used as explants in Agrobacterium-mediated transformation to produce genetically engineered grapevine plants of the cultivars 'Chardonnay' and 'BRS Clara' (Fig. 1a, b). Embryos and shoots growing on selective hygromycin media and expressing the construct reporter genes (Fig. 1a-c) were recovered at approximately similar rates $(3.21 \% \pm 0.38$ and $2.76 \% \pm 0.25$, respectively). A small portion of SE from both cultivars $(0.74 \% \pm 0.07)$ developed abnormal leafy cotyledons, and did not produce viable plants. Chimeric regenerants, identified by reporter gene expression analyses, represented 1.17 and $1.09 \%$ of the SAM- and SE-derived transformants, and were eliminated. External morphology, growth pattern, leaf color, and vigor of the rooted plants were identical to those of the wild type genotypes. Twenty-four genetically engineered lines carrying the genes of interest, along with the corresponding wild type and binary vector transformed controls were analyzed, and a selected subset, submitted to viral and fungal pathogen challenges (Table 1).

Histochemical detection of GUS activity was observed in leaf samples from all putative transgenic lines, as variable levels of diffuse staining after $24 \mathrm{~h}$ at $37{ }^{\circ} \mathrm{C}$ in the presence of glucuronide substrate (Fig. 1e). To quantify reporter gene expression, fluorometric readings of the reporter gene activity were determined. As observed for histochemical analyses, GUS activity evaluated by fluorometry was also variable for the transformed lines, ranging from 3740 to 950 pmol of MUG per h per mg of protein (Fig. 1f). Stable transgene insertion was confirmed by DNA hybridization analyses, and the estimated number of copies ranged from 1 to 3, employing DNA digested with a single cutter in the T-DNA and the T-DNA as probe (Fig. 1g, Table 1).

The genetically modified plants were further characterized by expression of the proteins with antimicrobial activity and biological challenges with a fungal pathogen by in vitro assays. The plants carrying virus RNA silencing constructs were propagated, gradually acclimated ex vitro, and challenged against GLRaV-3 by grafting.

\section{Disease responses to Botrytis cinerea}

Transgenic plants carrying CHIT and OLP constructs were maintained in vitro, by nodal segment propagation at 60-day intervals, and Botrytis pathogenesis was investigated by leaf disc assays for three representative lines of each construct (Table 1, Fig. 2).

RNA hybridization confirmed the transcription of the genes coding for proteins with antimicrobial activity in the tested transgenic lines (Fig. 2b, f). Chitinase activity was detected in wild type, nontransformed plants, although chitin degradation was approximately two times higher in lines carrying the CHIT construct (Fig. 2a). In contrast, the mRNA fragment of approximately $1 \mathrm{~kb}$ corresponding to MaCHIT1 was not detected in wild type plants, although cross hybridization with an $850 \mathrm{bp}$ fragment 
remained at the employed stringency (Fig. 2b). Levels of MaCHIT1 mRNA were higher in line 3, followed by line $2(32.5 \%$ of line 3$)$ and line 1 (17.5\% of line 3$)$, as inferred by densitometry analyses of the hybridization signal strength (Fig. 2b). Cross hybridization signal corresponded to $11.7 \%$ of the strongest signal (Fig. 2b). In pathogen challenged plants, chlorotic symptoms were visible on detached leaf discs 3 days after fungus inoculation, progressing to necrotic lesions at day 5 for wild type and genetically engineered CHIT2 and CHIT3 lines (Fig. 2c). Eleven days after inoculation, the affected leaf area was approximately 1.53 times smaller in CHIT lines $(60 \% \pm 3.06)$ than in the wild type $(92 \% \pm 4.12)$ (Fig. 2c), correspondingly the frequency of fungusderived structures was higher in wild type and empty pCambia1304 lines than in all three investigated CHIT lines (Fig. 2d).

Disease symptom progression in OLP lines was not distinct from the wild type control (Fig. 2e). At early infection stages (day 2-5), the percentage of affected leaf area progressed slightly faster in wild type control leaves, although not significantly (Fig. 2e). Complete leaf necrosis occurred at day 9 for all lines, preventing further investigation (Fig. 2e). Accordingly, the frequency of fungal conidiophore and hyphae was high in all lines at day 9 (Fig. 2g), although RNA hybridization analysis confirmed the presence of transcripts corresponding to $S n O L P$ in the investigated transgenic lines (Fig. 2f). Steady-state levels of SnOLP mRNA were similar in the three OLP lines (Fig. 2f).

Disease response to virus pathogens

Mature acclimated plants, carrying the hp-inducing construct, were grafted with lateral buds, positive for GLRaV-3, visually evaluated for typical leafroll symptoms, and molecularly characterized by PCR amplification of viral RNA sequences and CP antibody ELISA (Fig. $2 \mathrm{~h}-\mathrm{j}$ ). For all transformed lines more than one, out of the eight inoculated clones, exhibited the leafroll phenotype, except for the line pGLR3-3'SAM1, that displayed fainter symptoms (Fig. 2h). In agreement with visual observations, a GLRaV-3 specific fragment was successfully detected in pooled RNA samples from the genetically engineered lines (Fig. 2i).

Plants carrying hpRNA constructs exhibited lower virus titer than wild type and empty-vector containing plants; although detectable virus accumulation (CP levels) were present (Fig. 2j). For most lines, the levels of virus silencing tended to remain constant or slightly increase between the evaluations, except for lines pGLR3-5'-SE3 and pGLR3-5'-SAM1 (Fig. 2j). Average GLRaV-3 level of relative virus accumulation, corresponding to coat protein concentration, was approximately 3.2 and 2.4 times higher in wild type and empty vector transformed plants, respectively, in comparison to the levels found in hpRNA modified plants (Fig. 2j).

Constructs targeting the $5^{\prime}$ end of the virus gene were approximately $40 \%$ more effective to reduce the titers of virus coat protein, although the average copy number was also higher for the lines carrying the $5^{\prime}$ vector $(\mathrm{m}=1.67 \pm 0.52$ and $\mathrm{m}=1.34 \pm 0.52$, respectively) (Table 1, Fig. 2j). Moreover, the levels of virus silencing decreased in the second evaluation for two $5^{\prime}$ lines (Fig. 2j). Lines obtained from shoot apices had a higher average number of transgene copies $(\mathrm{m}=1.83 \pm 0.41)$, in comparison to those derived from somatic embryos $(m=1.17 \pm 0.41)$, and exhibited approximately $20 \%$ lower levels of silencing of virus replication (Table 1, Fig. 2j).

\section{Global genome methylation analyses}

The global contents of methylated DNA in wild type and genetically engineered grapevine lines were determined using a commercial ELISA-based method (Fig. 3). Methylated control DNA, provided by the manufacturer, was used to calculate a standard curve, which had a correlation coefficient higher than $93 \%$ (Fig. S3). The lowest levels of global genome methylation were found in untransformed controls (65.22 ng \pm 13.28$)$ and in plants carrying the empty binary vector (69.04 ng \pm 7.03 ) (Fig. 3). The different cultivars and explant types used in transformation did not significantly influence genome methylation contents ( $p$ values of 0.104 and 0.689 , respectively). Although differences in the methylation levels from biological replicates are routinely up to $20 \%$, as stated by the manufacturer, the amplitude of the readings was of 2.3 and $7.5 \%$ among CHIT and OLP lines, respectively (Fig. 3). In contrast, differences in methylation up to $47 \%$ among replicates were observed for lines carrying the hpRNA-inducing constructs (Fig. 3). Moreover, the magnitude of global genome methylation was higher for virus-derived 
constructs (157.1 ng \pm 58.2 ), with individual lines reaching more than $220 \mathrm{ng}$ of methylated DNA, in comparison to the plants carrying genes of interest of fungal and plant origin (122.8 $\mathrm{ng} \pm 41.5$ ) (Fig. 3).

To gain further insight on the response of genetically engineered grapevines to pathogen challenges, the variables transgene copy number, percentage of viral sequences in the T-DNA, reporter and disease resistance expression, and global genome methylation were submitted to multivariate analyses. A large portion of the observed variance $(84 \%)$ was explained by the first two principal components, although no clear association of the individuals to components was observed (Fig. S4). The variance/covariance structure of the data was better explained using linear combinations of the original variables in a sparse partial least square (sPLS) regression procedure using the origin of the gene of interest as discriminant (DA) (Fig. 4a). Hierarchical clustering of the sPLS-DA similarity matrix also demonstrated that lines carrying exogenous genes of plant and fungal origin exhibit distinct behavior in comparison to those of viral origin for the investigated variables (Fig. 4b). Reporter gene expression was the most divergent variable among the studied characteristics (Fig. 4c). Bivariate correlation analyses of the variables in the genetically engineered lines carrying resistance genes demonstrated a close association between the percentage of viral sequences in the T-DNA and the level of global genome methylation (Person's $\quad r=0.56690994$, $p$ value $<0.0039$ ) (Fig. 4d). The highest positive correlation was observed between transgene copy number and the percentage of viral sequences in the T-DNA (Person's $r=0.84749705, p$ value $<0.00$ ), as expected (Fig. 4d). In contrast, the highest negative correlation was observed between the expression of the reporter gene and resistance $(r=-0.7311262$, $p$ value $<0.00$ ) (Fig. 4d). In fact, the expression of the reporter gene was negatively correlated with all other investigated parameters, namely, contents of viral sequences in the T-DNA, genome methylation, and resistance expression (Fig. 4d).

\section{Discussion}

Biotic stresses, including fungal and viral diseases, are considered a major challenge to sustainable grapevine production worldwide (Burger et al. 2017). Novel biotechnological approaches allow precise breeding interventions in elite cultivars, via many tools of genetic engineering and genome editing (review in Gray et al. 2014). However, several non-accounted for factors appear to affect the manifestation of the introduced character, especially after long-term pathogen exposure or under heterogeneous environmental conditions (Gambino et al. 2010; Li et al. 2015; Rubio et al. 2015). In the present study, we have investigated the in vitro and in vivo response of genetically engineered grapevines to pathogen challenges, employing modified lines carrying genes of plant, fungal and viral origins that were obtained via two distinct explant regeneration pathways, namely: somatic embryogenesis and direct organogenesis from shoot apices.

Ectopic expression of proteins with antimicrobial activity slows down disease evolution

Grapevine responses to $B$. cinerea initially employ structural defense mechanisms, consisting of preexistent physical barriers, such as cuticle and trichomes (Wan et al. 2015). The initial responses are coupled with inducible pathways, leading to strengthening of the plant cell wall, secretion fungus cell wall degrading enzymes, and production of proteins involved in oxidative burst, or with antimicrobial properties (Haile et al. 2017). These responses were shown to restrict the growth of the invasive hyphae into the underlying plant tissues, which leads the pathogen to remain quiescent until favorable conditions occur and allow the evolution of pathogenesis (Haile et al. 2017). Changes in the plant developmental programs and cellular signals are hypothesized to trigger pathogen egression resuming the pathogenic process (Haile et al. 2017). The proteins ectopically expressed in the current study are associated to the initial stages of infection, namely: hydrolysis of the cell wall in several fungal structures (chitinase, in CHIT lines) (Bogo et al. 1998) and toxic effects to actively growing points (osmotin-like, in OLP lines) (Campos et al. 2008; Chowdhury et al. 2017).

The proteins $\mathrm{MaCHIT}$ and $\mathrm{SnOLP}$ were not capable of fully preventing fungal colonization of grapevine tissues, although they were demonstrated to be transcriptionally expressed and, in the case of CHIT, active. Detached leaf assays are considered drastic and may not reflect pathogenesis kinetics in intact plants 
(Liu et al. 2007). In detached Arabidopsis leaves, pathogenesis evolution against hemibiotrophic Colletotrichum species was compromised even in the presence of the functional resistance locus $\mathrm{RCH} 1$ (Liu et al. 2007). Botrytis cinerea pathogenesis relies on a combination of strategies to attack the plant cells, including the release of toxic metabolites, lytic enzymes, and microRNAs (Zhang et al. 2017). Thus, defense requires extensive transcriptional reprogramming and rarely results in complete symptom suppression (Zhang et al. 2017).

The rate of disease progression was reduced in most of the genetically engineered lines. In general, the ectopic expression of chitinase was more effective in delaying pathogenesis than of the osmotin-like protein. Fungal chitinases are classified to the glycosyl hydrolase (GH) 18 family and can be further separated into three groups and five classes (I-V), based on their domain architecture and sequence similarity (Langner and Göhre 2016). Although GH18 chitinases share a common catalytic mechanism, the enzymes are capable of endo and exoactivity, hydrolyzing sites within the polymer or from the termini (Langner and Göhre 2016). As shown previously, wild type grapevine plants also secrete native chitinases, such as the products of the genes VvCHITla (acidic class I chitinase) and $V v C H I T l b$ (basic class I chitinase) (Chong et al. 2008; Robert et al. 2002). Due to its catalytic activity towards fungal cell walls, hyphal tips, and germ tubes chitinase genes from plant and fungal origins have been widely employed in genetically engineered plants to increase disease resistance. As shown in our work, the ectopic expression of microbial chitinase genes slowed down disease progression, and reduced fungal colonization in a wide range of other genetically engineered species, including tobacco, apple, potato and pea expressing CHIT genes from Rhizopus oligosporus (Terakawa et al. 1997), Saccharomyces cerevisiae (Carstens et al. 2003), Trichoderma atroviride (Bolar et al. 2001), Streptomyces griseus (Raham et al. 2008) or Streptomyces olivaceoviridis (Hassan et al. 2009). As observed in previous studies (Núñez de Cáceres González et al. 2015; Yamamoto et al. 2000), our results also demonstrated that higher levels of chitinase activity resulted in slower pathogen colonization.

Originally, osmotin was identified as a salt-induced protein in tobacco (Nicotiana tabacum L.) cells (Singh et al. 1989). With the increase of genomic data, osmotin and OLPs were demonstrated to be part of the widespread superfamily of thaumatin-like proteins (TLP) (Liu et al. 2010). In general, the antifungal features of TLPs are attributed to the variety of enzymatic activities displayed by these proteins against microorganism cell walls, including glucanase and other pore forming activities (Chowdhury et al. 2015; Liu et al. 2010). Endogenous and ectopic OLPs were also shown to participate in the defense against biotic factors, by controlling cellular processes common to a wide range of stresses, such as scavenging of oxidative burst and maintenance of turgor pressure (Choi et al. 2013; Chowdhury et al. 2017; Das et al. 2011; Weber et al. 2014; Zhu et al. 1995). However, our in vivo challenge results demonstrated extensive presence of $B$. cinerea structures in the leaf tissue of OLP lines, and only a slight effect on disease progression, restricted to the initial stages of pathogenesis. These effects may be due to insufficient expression levels, since a dosage-dependent response has been observed in in vitro (Chowdhury et al. 2015) and in vivo (Chowdhury et al. 2017) studies against fungi. Alternatively, the selective mechanism of necrotrophic pathogens, such as $B$. cinerea, against plant OLPs and chitinases (Marcato et al. 2017) may have contributed to the low manifestation of resistance in the lines expressing proteins with antimicrobial activity.

Expression of hpRNA inducing viral sequences reduces GLRaV-3 titer in grafted plants

In plants, biotechnological applications aiming antiviral protection frequently employs RNA interference (RNAi)-based mechanisms. These systems employ the genetically engineered expression of double-stranded (dsRNA) cognate to a target viral sequence to trigger endogenous antiviral pathways in the host plant (Pooggin 2017). Constructions of intron-spliced hairpin RNA with inverted repeats of a viral sequence are considered highly effective in silencing the target sequences (Smith et al. 2000). However, the engineered degradation of viral sequences was demonstrated to be unstable, due to transcriptional and posttranscriptional RNA-mediated mechanisms (Lewsey et al. 2016) and antiviral protection is not always achieved, despite the accumulation of transgene coded sRNAs (López et al. 2010; Ribeiro et al. 2007). In grapevine, genetic engineering employing sequences 
of viral origin frequently results in low or unstable mRNA and protein accumulation (Gambino et al. 2005; Mauro et al. 1995; Vigne et al. 2004).

In our study, lower viral titers were observed in genetically engineered grapevine lines carrying hairpin-inducing constructs for the $3^{\prime}$ or $5^{\prime}$ termini of the coat protein gene of a local GLRaV-3 isolate, in comparison to the wild type and empty vector controls, although leaf roll symptoms and virus replication were detected in hpRNA lines. The assessment of the contribution of transgene-mediated responses to viral resistance in genetically engineered grapevines is not straightforward, due to the activation of the endogenous post-transcriptional gene silencing mechanism upon virus infection (Gambino et al. 2010; Hewezi et al. 2017; Singh et al. 2012). Moreover, leafroll disease is currently associated to a complex of six viruses, designated as GLRaV-1, -2, -3, -4 (and its strains), -7 and -13 , which are genetically diverse in genome size, organization, and gene content (Burger et al. 2017). The GLRaV-3 group itself is highly diverse, consisting of, at least, eight distinct clades, with significant variation in viral genome sequence, and in length of the $5^{\prime}$ untranslated regions (Burger et al. 2017). Genetic variants of GLRaVs are frequently found in a single plant due to the clonal propagation of grapevine, the absence of natural resistance sources in Vitis spp., and the intrinsically error-prone nature of viral genome replication (Burger et al. 2017). Thus, the occurrence of unaccounted for or uncharacterized viruses may have contributed to the observed leafroll symptoms. Moreover, the use of molecular methods based on partial sequence information, such as in gene-specific amplifications and serological analyses, is also considered imprecise to characterize GLRaV coinfections and mixed infections with other viruses (Burger et al. 2017). The comparison of virus titers between genetically engineered and control plants suggests that, besides the common endogenous RNA silencing mechanism triggered by grafting, the insertion of the hp-inducing construct promoted further protection but was ineffective to fully prevent replication and pathogenesis by GLRaV-3 and related variants. The actual contribution of the inserted constructs remains to be determined.
Global genome methylation correlates positively with the contents of virus-derived sequences

DNA methylation consists of an important epigenetic mechanism associated to transcriptional regulation and silencing of repetitive and mobile transposable elements (Seymour and Becker 2017). Three distinct contexts of methylation occur in plants; at the CG, $\mathrm{CHG}$ (where $\mathrm{H}$ is $\mathrm{A}, \mathrm{T}$, or $\mathrm{C}$ ), and $\mathrm{CHH}$, each requiring specific subsets of effector enzymes and cofactors (Seymour and Becker 2017). The genomic stress associated to developmental and metabolic reprograming in tissue culture promotes epigenetic changes, likely to be different depending on the genomic context (Miyao et al. 2012). The hybrid cultivar 'BRS Clara' and the vinifera 'Chardonnay' exhibited similar levels of global genome methylation, although complex plant genomes tend to display higher contents of methylated DNA (Seymour and Becker 2017). It is likely to be due to the small percentage of wild Vitis in 'BRS Clara' genome (less than $15 \%$ ) and to global nature of the analysis that does not target methylation-prone sequences. In grapevine, tissue culture variants of 'Chardonnay' and 'Syrah' were demonstrated to have altered patterns of genome wide methylation, investigated by Methylation Sensitive Amplified Polymorphism (MSAP) (Baránek et al. 2010; Schellenbaum et al. 2008). In contrast, molecular markers based exclusively on DNA sequence, such as Simple Sequence Repeat (SSR) and Amplified Fragment Length Polymorphism (AFLP), were less effective to detect genomic differences between variants and the original cultivar, suggesting that tissue culture induced epigenetic changes are transient in grapevine (Schellenbaum et al. 2008). Most of the non-transient epigenetic changes induced by tissue culture techniques in Vitis consist of mitoticallyinherited epimutations and include regions subject to methylation modifications in response to stress in other plant genomes, such as retrotransposon and methyltransferase sequences (Baránek et al. 2015). In agreement, our results demonstrated that genetic engineering was responsible for higher levels of global genome methylation in comparison to tissue culture alone. Moreover, methylation levels were positively correlated to larger portions of repetitive (transgene copy numbers) and viral sequences (promoter and gene of interest). In a similar study, genetically engineered grapevine lines, carrying the 
full-length sense or antisense sequence of the $\mathrm{CP}$ gene of the grapevine fanleaf virus (GFLV), exhibited a weak correlation between T-DNA copy number and the accumulation of its mRNA and coat protein (Gambino et al. 2005). In a subsequent study, the authors demonstrated, employing bisulphite sequencing, that methylation of sequences of viral origin was frequent in lines with complex rearrangements of the inserted T-DNA (Gambino et al. 2010). The genetic changes caused by the insertion of exogenous sequences in plant genomes are clearly associated to epigenetic modifications, although the correlation between DNA methylation and gene expression is low, but significant (Seymour and Becker 2017).

Disease resistance expression correlates

negatively to global genomic methylation

The ectopic proteins used to produce genetically modified grapevines, namely a fungal chitinase and a Solanum nigrum thaumatin-like protein, are part of the plant basal defense mechanism, shared by pathways triggered against necrotrophic, biotrophic and hemibiotrophic fungi. Genetically engineered grapevines carrying similar proteins with antimicrobial activity showed variable levels of tolerance to fungal pathogens, although rarely of complete immunity (Gray et al. 2014). Accordingly, in our study the expression of CHIT or OLP delayed pathogenesis in grapevine leaves challenged with $B$. cinerea. However, symptoms and pathogen growth were observed in in vitro assays for all modified lines. Chitinase engineered grapevines were also shown to exhibit susceptibility levels like those of wild type plants (Bornhoff et al. 2005; Rubio et al. 2015). Cisgenic grapevines expressing the coding sequences of thaumatin-like proteins from 'Chardonnay' and Vitis amurensis exhibited delayed pathogenesis against fungal pathogens (Dhekney et al. 2011; He et al. 2017). In general, these studies demonstrated variable levels of resistance among lines and biological challenge conditions, such as in vitro, greenhouse or field assays (Gray et al. 2014; He et al. 2017; Rubio et al. 2015). Genetic engineering aiming to induce silencing of virusderived sequences was extensively used in grapevine (Gray et al. 2014; Maliogka et al. 2015), although mRNA and protein accumulation was demonstrated to be low or unstable, and to show a weak correlation with disease expression (Gambino et al. 2005; Mauro et al. 1995; Vigne et al. 2004). The inconsistent patterns of resistance manifestation in genetically engineered grapevines suggest that uncharacterized factors also contribute to the response phenotype and epigenetic modifications are currently considered contributors to the phenotype of genetically modified plants (Ji et al. 2015; Lewsey et al. 2016; Matzke et al. 2015).

In Arabidopsis thaliana and rice, the loss of function of genes crucial to genome methylation pathways only affects marginally the global patterns of gene expression (review in Seymour and Becker 2017), suggesting that DNA methylation is responsible for the control of the expression of a small number of endogenous loci. However, genomic feature and position are also known to influence the associations between DNA methylation and gene expression (Seymour and Becker 2017). In agreement, our results of the multivariate response regression with discriminant analysis of partial least squares suggested a significant association between the global levels of genome methylation and the expression of resistance in genetically engineered plants. Moreover, our results also demonstrate that the origin of the inserted sequences is an important factor contributing to the degree of global epigenetic changes in the host genome.

The expression of the reporter gene gusA in genetically engineered grapevine lines was negatively correlated to the transgene copy number, the portion of introduced sequences of viral origin, and the levels of global genome methylation.

Acknowledgements The authors would like to thank the following for kindly sharing their expertise and excellent assistance: Renata Gava for fungus growth and aid with pathogenesis analyses, and Heitor Corbelini for grafting and conducting the plants in the greenhouse. The work was financed by Conselho Nacional de Desenvolvimento Científico e Tecnológico (CNPq) (Grant No. 381107/97-3)/BioEX and Sistema Embrapa de Gestão (SEG) (Grant No. 03.08.06.003.00.00) to PSR, TVMF, UAC and VQ.

Author contributions DDB, IS and VQ performed genetic transformation experiments, plant selection and culture, fungal pathogen challenges, and insertion/expression molecular analyses. PSR and UAC designed the strategies for fungal disease resistance, and selected the grapevine cultivars. $\mathrm{RH}$ and TVMF designed and constructed the virus hairpin-inducing constructs and performed viral pathogen challenges. PSR, UAC, TVMF and VQ conceived the work, analyzed the results and drafted the manuscript. 


\section{Compliance with ethical standards}

Conflict of interest The authors declare that they have no conflict of interest.

\section{References}

Baránek M, Křižan B, Ondrušiková E, Pidra M (2010) DNAmethylation changes in grapevine somaclones following in vitro culture and thermotherapy. Plant Cell Tissue Organ Cult 101:11-22. https://doi.org/10.1007/s11240-0099656-1

Baránek M, Čechová J, Raddová J, Holleinová V, Ondrušíková E, Pidra M (2015) Dynamics and reversibility of the DNA methylation landscape of grapevine plants (Vitis vinifera) stressed by in vitro cultivation and thermotherapy. PLoS ONE 10(5):e0126638. https://doi.org/10.1371/journal. pone. 0126638

Bogo MR, Rota CA, Pinto H Jr, Ocampos M, Correa CT, Vainstein MH, Schrank A (1998) A chitinase encoding gene (chitl gene) from the entomopathogen Metarhizium anisopliae: isolation and characterisation of genomic and full-length cDNA. Curr Microbiol 73:221-225. https://doi. org/10.1007/s002849900368

Bolar JP, Norelli JL, Harman GE, Brown SK, Aldwinckle HS (2001) Synergistic activity of endochitinase and exochitinase from Trichoderma atroviride (T. harzianum) against the pathogenic fungus (Venturia inaequalis) in transgenic apple plants. Transgenic Res 10(6):533-543. https://doi. org/10.1023/A:1013036732691

Bornhoff BA, Harst M, Zyprian E, Topfer R (2005) Transgenic plants of Vitis vinifera 'Seyval Blanc'. Plant Cell Rep 24:433-438. https://doi.org/10.1007/s00299-005-0959-3

Breen S, Solomon PS, Bedon F, Vincent D (2015) Surveying the potential of secreted antimicrobial peptides to enhance plant disease resistance. Front Plant Sci 6:900. https://doi. org/10.3389/fpls.2015.00900.eCollection

Burger JT, Maree HJ, Gouveia P, Naidu RA (2017) Grapevine leafroll-associated virus 3. In: Meng B, Martelli GP, Golino DA, Fuchs M (eds) Grapevine viruses: molecular biology, diagnostics and management. Springer, Cham, pp 167-195. https://doi.org/10.1007/978-3-319-57706-7

Camargo UA, Nachtigal JC, Maia JDG, Oliveira PRD, Protas JFS (2003) BRS Clara: nova cultivar de uva branca de mesa sem semente. Bento Gonçalves: Embrapa Uva e Vinho (Comunicado Técnico, 46). https://ainfo.cnptia.embrapa. br/digital/bitstream/CNPUV/5274/1/cot046.pdf. Accessed 12 May 2015

Campos Ma, Silva MS, Magalhães CP, Ribeiro SG, Sarto RP, Vieira EA, Grossi de Sá MF (2008) Expression in Escherichia coli, purification, refolding and antifungal activity of an osmotin from Solanum nigrum. Microb Cell Fact 7:7. https://doi.org/10.1186/1475-2859-7-7

Carstens M, Vivier MA, Pretorius IS (2003) The Saccharomyces cerevisiae chitinase, encoded by the CTS1-2 gene, confers antifungal activity against Botrytis cinerea to transgenic tobacco. Transgenic Res 12:497-508. https://doi.org/10. 1023/A: 1024220023057
Choi DS, Hong JK, Hwang BK (2013) Pepper osmotin-like protein 1 (CaOSM1) is an essential component for defense response, cell death, and oxidative burst in plants. Planta 238(6):1113-1124. https://doi.org/10.1007/s00425-0131956-3

Chong J, Le Henanff G, Bertsch C, Walter B (2008) Identification, expression analysis and characterization of defense and signaling genes in Vitis vinifera. Plant Physiol Biochem 46:469-481. https://doi.org/10.1016/j.plaphy.2007. 09.010

Chowdhury S, Basu A, Kundu S (2015) Cloning, characterization, and bacterial over-expression of an osmotin-like protein gene from Solanum nigrum L. with antifungal activity against three necrotrophic fungi. Mol Biotechnol 57(4):371-381. https://doi.org/10.1007/s12033-014-98314

Chowdhury S, Basu A, Kundu S (2017) Overexpression of a new osmotin-like protein gene (SindOLP) confers tolerance against biotic and abiotic stresses in sesame. Front Plant Sci 8:410. https://doi.org/10.3389/fpls.2017.00410

Das M, Chauhan H, Chhibbar A, Rizwanul Haq QM, Khurana P (2011) High-efficiency transformation and selective tolerance against biotic and abiotic stress in mulberry, Morus indica $\mathrm{cv}$. K2, by constitutive and inducible expression of tobacco osmotin. Transgenic Res 20(2):231-246. https:// doi.org/10.1007/s11248-010-9405-6

Dhekney S, Li Z, Gray DJ (2011) Grapevines engineered to express cisgenic Vitis vinifera thaumatin-like protein exhibit fungal disease resistance. In Vitro Cell Dev Biol Plant 47:458-466. https://doi.org/10.1007/s11627-0119358-3

Dutt M, Li ZT, Dhekney SA, Gray DJ (2007) Transgenic plants from shoot apical meristems of Vitis vinifera L. "Thompson Seedless" via Agrobacterium-mediated transformation. Plant Cell Rep 26(12):2101-2110. https://doi.org/10. 1007/s00299-007-0424-6

Fajardo TVM, Dianese EC, Eiras M, Cerqueira DM, Lopes DB, Ferreira MASV, Martins CRF (2007) Variability of the coat protein gene of Grapevine leafroll-associated virus 3 in Brazil. Fitopatol Bras 32(4):335-340. https://doi.org/10. 1590/S0100-41582007000400008

Fox J, Weisberg S (2011) An R companion to applied regression. Sage, Thousand Oaks. http://socserv.socsci. mcmaster.ca/jfox/Books/Companion

Gadoury DM, Seem RC, Wilcox WF, Henick-Kling T, Conterno L, Day A, Ficke A (2007) Effects of diffuse colonization of grape berries by Uncinula necator on bunch rots, berry microflora, and juice and wine quality. Phytopathology 97(10):1356-13565. https://doi.org/10.1094/PHYTO-9710-1356

Gambino G, Gribaudo I, Leopold S, Schartl A, Laimer M (2005) Molecular characterization of grapevine plants transformed with GFLV resistance genes: I. Plant Cell Rep 24:655-662. https://doi.org/10.1007/s00299-005-0006-4

Gambino G, Perrone I, Gribaudo I (2008) A rapid and effective method for RNA extraction from different tissues of grapevine and other woody plants. Phytochem Anal 19(6):520-525. https://doi.org/10.1002/pca.1078 
Gambino G, Perrone I, Carra A, Chitarra W, Boccacci P, Torello Marinoni D, Barberis M, Maghuly F, Laimer M, Gribaudo I (2010) Transgene silencing in grapevines transformed with GFLV resistance genes: analysis of variable expression of transgene, siRNAs production and cytosine methylation. Transgenic Res 19(1):17-27. https://doi.org/10.1007/ s11248-009-9289-5

Gamborg O, Miller RA, Ojima K (1968) Nutrient requirement of suspensions cultures of soybean root cells. Exp Cell Res 50:151-155

Gray DJ, Li ZT, Dhekney SA (2014) Precision breeding of grapevine (Vitis vinifera L.) for improved traits. Plant Sci 228:3-10. https://doi.org/10.1016/j.plantsci.2014.03.023

Haile ZM, Pilati S, Sonego P, Malacarne G, Vrhovsek U, Engelen K, Tudzynski P, Zottini M, Baraldi E, Moser C (2017) Molecular analysis of the early interaction between the grapevine flower and Botrytis cinerea reveals that prompt activation of specific host pathways leads to fungus quiescence. Plant Cell Environ 40(8):1409-1428. https:// doi.org/10.1111/pce.12937

Harrell Jr FE, With contributions from Charles Dupont and many others (2017) Hmisc: harrell miscellaneous. R package version 4.0-3. https://CRAN.R-project.org/ package $=$ Hmisc. Accessed 22 Dec 2017

Hassan F, Meens J, Jacobsen H, Kiesecker H (2009) A family 19 chitinase (Chit30) from Streptomyces olivaceoviridis ATCC 11238 expressed in transgenic pea affects the development of $T$. harzianum in vitro. $\mathrm{J}$ Biotechnol 143:302-330. https://doi.org/10.1016/j.jbiotec.2009.08. 011

He R, Wu J, Zhang Y, Agüero CB, Li X, Liu S, Wang C, Walker MA, Lu J (2017) Overexpression of a thaumatin-like protein gene from Vitis amurensis improves downy mildew resistance in Vitis vinifera grapevine. Protoplasma 254(4):1579-1589. https://doi.org/10.1007/s00709-0161047-y

Hewezi T, Pantalone V, Bennett M, Neal Stewart C, BurchSmith TM Jr (2017) Phytopathogen-induced changes to plant methylomes. Plant Cell Rep. https://doi.org/10.1007/ s00299-017-2188-y

Iocco P, Franks T, Thomas MR (2001) Genetic transformation of major wine grape cultivars of Vitis vinifera L. Transgenic Res 10(2):105-112. https://doi.org/10.1023/A: 1008989610340

Jardak-Jamoussi R, Winterhagen P, Bouamama B, Dubois C, Mliki A, Wetzel T, Ghorbel A, Reustle GM (2009) Development and evaluation of GFLV inverted repeat construct for genetic transformation of grapevine. Plant Cell Tissue Organ Cult 97:187-196. https://doi.org/10. 1007/s11240-009-9514-1

Jelly NS, Schellenbaum P, Walter B, Maillo P (2012) Transient expression of artificial microRNAs targeting Grapevine fanleaf virus and evidence for RNA silencing in grapevine somatic embryos. Transgenic Res 21(6):1319-1327. https://doi.org/10.1007/s11248-012-9611-5

Langner T, Göhre V (2016) Fungal chitinases: function, regulation, and potential roles in plant/pathogen interactions. Curr Genet 62(2):243-254. https://doi.org/10.1007/ s00294-015-0530-x

Lê Cao K-A, Rohart F, Gonzalez I, Dejean S with Key Contributors Gautier B, Bartolo F, Contributions from Monget
P, Coquery J, Yao F, Liquet B (2016). mixOmics: omics data integration project. R package version 6.1.1. https:// CRAN.R-project.org/package $=$ mixOmics. Accessed 16 Feb 2017

Lewsey MG, Hardcastle TJ, Melnyk CW, Molnar A, Valli A, Urich MA, Nery JR, Baulcombe DC, Ecker JR (2016) Mobile small RNAs regulate genome-wide DNA methylation. Proc Natl Acad Sci USA 113(6):E801-E810. https://doi.org/10.1073/pnas.1515072113

Li ZT, Hopkins DL, Gray DJ (2015) Overexpression of antimicrobial lytic peptides protects grapevine from Pierce's disease under greenhouse but not field conditions. Transgenic Res 24(5):821-836. https://doi.org/10.1007/ s11248-015-9876-6

Li ZT, Dhekney S, Dutt M, Van Aman M, Tattersall J, Kelley KT, Gray DJ (2006) Optimizing Agrobacterium-mediated transformation of grapevine. In Vitro Cell Dev Biol—Plant 42(3):220-227. https://doi.org/10.1079/IVP2006770

Liu G, Kennedy R, Greenshields DL, Peng G, Forseille L, Selvaraj G, Wei Y (2007) Detached and attached Arabidopsis leaf assays reveal distinctive defense responses against hemibiotrophic Colletotrichum spp. Mol Plant Microbe Interact 20(10):1308-1319. https://doi.org/10. 1094/MPMI-20-10-1308

Liu JJ, Sturrock R, Ekramoddoullah AK (2010) The superfamily of thaumatin-like proteins: its origin, evolution, and expression towards biological function. Plant Cell Rep 29(5):419-436. https://doi.org/10.1007/s00299-010-08268

Lodhi MA, Ye G-N, Weeden NF, Reisch BI (1994) A simple and efficient method for DNA extraction from grapevine cultivars, Vitis species and Ampelopsis. Plant Mol Biol Rep 12(1):6-13. https://doi.org/10.1007/BF02668658

López C, Cervera M, Fagoaga C, Moreno P, Navarro L, Flores R, Peña L (2010) Accumulation of transgene-derived siRNAs is not sufficient for RNAi-mediated protection against Citrus tristeza virus in transgenic Mexican lime. Mol Plant Pathol 11(1):33-41. https://doi.org/10.1111/j. 1364-3703.2009.00566.x

Maliogka VI, Martelli GP, Fuchs M, Katis NI (2015) Control of viruses infecting grapevine. Adv Virus Res 91:175-227. https://doi.org/10.1016/bs.aivir.2014.11.002

Marcato R, Sella L, Lucchetta M, Vincenzi S, Odorizzi S, Curioni A, Favaron F (2017) Necrotrophic fungal plant pathogens display different mechanisms to counteract grape chitinase and thaumatin-like protein. Physiol Mol Plant Pathol 99:7-15. https://doi.org/10.1016/j.pmpp. 2016.09.005

Matzke MA, Kanno T, Matzke AJ (2015) RNA-directed DNA methylation: the evolution of a complex epigenetic pathway in flowering plants. Annu Rev Plant Biol 66:243-267. https://doi.org/10.1146/annurev-arplant-043014-114633

Mauro MC, Toutain A, Walter B, Pinck L, Otten L, CoutosThevenot P, Deloire A, Barbier P (1995) High efficiency regeneration of grapevine plants transformed with the GFLV coat protein gene. Plant Sci 112:97-106. https://doi. org/10.1016/0168-9452(95)04246-Q

Miyao A, Nakagome M, Ohnuma T, Yamagata H, Kanamori H, Katayose Y, Takahashi A, Matsumoto T, Hirochika H (2012) Molecular spectrum of somaclonal variation in regenerated rice revealed by whole-genome sequencing. 
Plant Cell Physiol 53(1):256-264. https://doi.org/10.1093/ pcp/pcr172

Murashige T, Skoog F (1962) A revised medium for rapid growth and bioassays with tobacco tissue culture. Physiol Plant 15:473-497

Núñez de Cáceres González FF, Davey MR, Cancho Sanchez E, Wilson ZA (2015) Conferred resistance to Botrytis cinerea in Lilium by overexpression of the $\mathrm{RCH} 10$ chitinase gene. Plant Cell Rep 34(7):1201-1209. https://doi.org/10.1007/ s00299-015-1778-9

Pooggin MM (2017) RNAi-mediated resistance to viruses: a critical assessment of methodologies. Curr Opin Virol 26:28-35. https://doi.org/10.1016/j.coviro.2017.07.010

R Core Team (2015) R: a language and environment for statistical computing. R Foundation for Statistical Computing, Vienna. http://www.R-project.org/

Raham SK, Rinaldi S, Ikuo N, Masahiro M (2008) Production of transgenic potato exhibiting enhanced resistance to fungal infections and herbicide applications. Plant Biotechnol Rep 2:13-20

Ribeiro SG, Lohuis H, Goldbach R, Prins M (2007) Tomato chlorotic mottle virus is a target of RNA silencing but the presence of specific short interfering RNAs does not guarantee resistance in transgenic plants. J Virol 81(4):1563-1573. https://doi.org/10.1128/JVI.01238-06

Robert N, Roche K, Lebeau Y, Breda C, Boulay M, Esnault R, Buffard D (2002) Expression of grapevine chitinase genes in berries and leaves infected by fungal or bacterial pathogens. Plant Sci 162:389-400. https://doi.org/10.1016/ S0168-9452(01)00576-3

Rubio J, Montes C, Castro Á, Álvarez C, Olmedo B, Muñoz M, Tapia E, Reyes F, Ortega M, Sánchez E, Miccono M, Dalla Costa L, Martinelli L, Malnoy M, Prieto H (2015) Genetically engineered Thompson Seedless grapevine plants designed for fungal tolerance: selection and characterization of the best performing individuals in a field trial. Transgenic Res 24(1):43-60. https://doi.org/10.1007/ s11248-014-9811-2

Schellenbaum P, Mohler V, Wenzel G, Walter B (2008) Variation in DNA methylation patterns of grapevine somaclones (Vitis vinifera L.). BMC Plant Biol 15(8):78. https:// doi.org/10.1186/1471-2229-8-78

Schneider CA, Rasband WS, Eliceiri KW (2012) NIH Image to ImageJ: 25 years of image analysis. Nat Methods 9:671-675. https://doi.org/10.1038/nmeth.2089

Seymour DK, Becker C (2017) The causes and consequences of DNA methylome variation in plants. Curr Opin Plant Biol 36:56-63. https://doi.org/10.1016/j.pbi.2017.01.005

Singh NK, Nelson DE, Kuhn D, Hasegawa PM, Bressan PA (1989) Molecular cloning of osmotin and regulation of its expression by $\mathrm{ABA}$ and adaptation to low water potential.
Plant Physiol 90:1096-1101. https://doi.org/10.1104/pp. 90.3.1096

Smith NA, Singh SP, Wang MB, Stoutjesdijk PA, Green AG, Waterhouse PM (2000) Total silencing by intron-spliced hairpin RNAs. Nature 407(6802):319-320. https://doi.org/ 10.1038/35030305

Terakawa T, Takaya N, Horiuchi H, Koike M, Takagi M (1997) A fungal chitinase gene from Rhizopus oligosporus confers antifungal activity to transgenic tobacco. Plant Cell Rep 16:439-443. https://doi.org/10.1007/BF01092762

Valat L, Fuchs M, Burrus M (2006) Transgenic grapevine rootstock clones expressing the coat protein or movement protein genes of Grapevine fanleaf virus: characterization and reaction to virus infection upon protoplast electroporation. Plant Sci 170:739-747. https://doi.org/10.1016/j. plantsci.2005.11.005

Vigne E, Komar V, Fuchs M (2004) Field safety assessment of recombination in transgenic grapevines. Transgenic Res 13:165-179. 0000026075.79097.c9

Wan R, Hou X, Wang X, Qu J, Singer SD, Wang Y, Wang X (2015) Resistance evaluation of Chinese wild Vitis genotypes against Botrytis cinerea and different responses of resistant and susceptible hosts to the infection. Front Plant Sci 6:854. https://doi.org/10.3389/fpls.2015.00854

Weber RL, Wiebke-Strohm B, Bredemeier C, Margis-Pinheiro M, de Brito GG, Rechenmacher C, Bertagnolli PF, de Sá ME, Campos MA, de Amorim RM, Beneventi MA, Margis R, Grossi-de-Sa MF, Bodanese-Zanettini MH (2014) Expression of an osmotin-like protein from Solanum nigrum confers drought tolerance in transgenic soybean. BMC Plant Biol 14:343. https://doi.org/10.1186/s12870014-0343-y

Wright K (2017) Corrgram: plot a correlogram. R package version 1.12. https://CRAN.R-project.org/package= corrgram. Accessed 8 June 2017

Yamamoto T, Iketani H, Ieki H, Nishizawa Y, Notsuka K, Hibi T, Hayashi T, Matsuta N (2000) Transgenic grapevine plants expressing a rice chitinase with enhanced resistance to fungal pathogens. Plant Cell Rep 19:639-646. https:// doi.org/10.1007/s002999900174

Zhang W, Corwin JA, Copeland D, Feusier J, Eshbaugh R, Chen F, Atwell S, Kliebenstein DJ (2017) Plastic transcriptomes stabilize immunity to pathogen diversity: the jasmonic acid and salicylic acid networks within the Arabidopsis/Botrytis pathosystem. Plant Cell 29(11):2727-2752. https://doi.org/ 10.1105/tpc. 17.00348

Zhu B, Chen TH, Li PH (1995) Activation of two osmotin-like protein genes by abiotic stimuli and fungal pathogen in transgenic potato plants. Plant Physiol 108(3):929-937. https://doi.org/10.1104/pp.108.3 